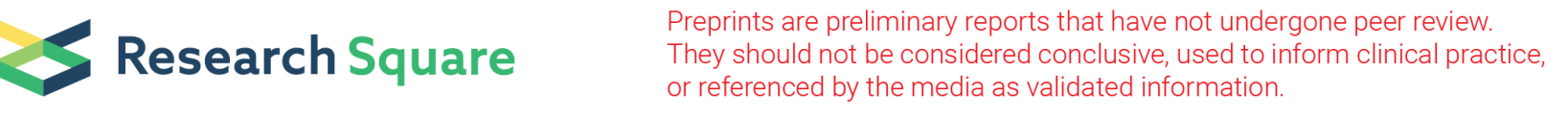

\title{
Cost Profiling of Tyrosine Kinase Inhibitors for Chronic Myeloid Leukemia Treatment in South Africa: Medicines That Are Still Too Expensive to Swallow
}

\author{
Reeya Singh \\ University of KwaZulu-Natal \\ Frasia Oosthuizen \\ University of KwaZulu-Natal \\ Ebenezer Wiafe ( $\sim$ weben38@gmail.com ) \\ University of KwaZulu-Natal \\ Kofi Boamah Mensah \\ Kwame Nkrumah University of Science and Technology \\ Varsha Bangalee \\ University of KwaZulu-Natal
}

\section{Research Article}

Keywords: Chronic myeloid leukemia, Cost-profiling, South Africa, Tyrosine kinase inhibitor.

Posted Date: August 6th, 2021

DOl: https://doi.org/10.21203/rs.3.rs-751789/v1

License: (c) (i) This work is licensed under a Creative Commons Attribution 4.0 International License. Read Full License 


\section{Abstract \\ Background}

The development of tyrosine kinase inhibitors (TKIs) has improved chronic myeloid leukemia (CML) management and increased CML prevalence due to low mortality rates. CML management is potentially lifelong and expensive and requires pharmacoeconomic approaches and regular review of therapy to ensure that patients obtain cost-effective therapeutic outcomes. Although the introduction of TKIs generics has improved the availability of TKIs, the high-cost implications continue to hinder TKIs accessibility and translate into poor quality of life. To improve the availability and accessibility of TKIs in South Africa, interventional programs have been instrumental. A notable intervention is the collaborative effort of Novartis pharmaceuticals and The Max Foundation which has provided free access to Imatinib to patients in need. In recognition of the needs of CML patients, this study aimed to provide an overview of TKIs regulatory approval, availability, and cost profile in the South African (SA) context for the 2019 period.

\section{Methods}

The researchers searched the South African Health Products Regulatory Authority (SAHPRA) website on 20 August 2019 to identify TKIs, generic and innovator brands, that was duly registered. The costs of the registered TKIs were extracted from the Medicines Price Registry (2019) and the Department of Health awarded tenders for oncology medications (2019). The results were analysed quantitatively using Microsoft Excel and presented as tables.

\section{Results}

Three TKIs were registered in SA: Imatinib, Dasatinib, and Nilotinib. Generics were only available for Imatinib. Despite the numerous Imatinib generics available in the private sector, treatment for CML chronic phase (CP) patients in the private sector was more expensive than in the public sector. Apparent cost inequality was noted where the same TKI (Nilotinib 200 $\mathrm{mg}$ ) costs substantially less (by $92.4 \%$ ) in the public sector than in the private sector.

\section{Conclusion}

The study concluded that the accessibility to CML management in the private sector is hindered by the high cost of therapy compared to the public sector. The availability of generic forms of Imatinib eliminated monopoly and improved medicated access compared to Dasatinib and Nilotinib. To improve CML medication access, stakeholders' engagement is required to control cost.

\section{Introduction}

Tyrosine kinase inhibitors (TKIs) have radically improved the treatment of chronic myeloid leukemia (CML), a rare myeloproliferative disease defined by the excessive production of myeloid cells, both mature and immature, in the bone marrow, blood, and spleen [1]. CML has three phases, namely the chronic phase (CP), accelerated phase (AP), and the blast phase (BP). In greater than $90 \%$ of $C M L$ cases, diagnosis is made during the $C P$; if untreated $C M L$ will progress into the initial AP and thereafter to the more aggressive BP [1]. Widespread and successful use of TKls has resulted in an increased number of CML patients surviving with a near-normal life expectancy, subsequently increasing the prevalence of this disease [2]. The ultimate goal of CML treatment is normal survival and good quality of life without lifelong treatment. In resource-poor developing countries, the unavailability of effective drugs and limited essential monitoring systems result in the goal of treatment remaining as survival [3]. 
The treatment of CML with TKls therapy attracts high costs coupled with recommended lifelong therapy [4], which translates to a significant burden on health care systems. In South Africa (SA) there are three active pharmaceutical ingredients of cellular TKIs registered by the South African Health Products Regulatory Authority (SAHPRA); namely Imatinib, Dasatinib, and Nilotinib [5]. All three TKIs are available in the private health sector whereas only two TKIs (Imatinib and Nilotinib) are available on tender in the public health sector [6]. Access to TKIs significantly impacts the management of CML. Therefore, only two TKIs for CML treatment are readily available in the SA public sector.

The SA access to TKIs has increased through patient assistance programs and clinical trials. Patient assistance programs such as the Glivec International Patient Assistance Program (GIPAP), which was set up as a partnership between Novartis and The Max Foundation in 2002, have supplied Imatinib at no cost to poorer patients [7, 8]. The two organizations collaborated to ensure that patients with CML or Gastrointestinal Stromal Tumor (GIST) received treatment. The GIPAP was a direct-to-patient access program introduced after Novartis recognized the impact that Glivec had on CML and GIST. Novartis assumed responsibility of managing the supply chain for the medicine and interacted with local stakeholders such as physicians, pharmacists, treatment centers, non-governmental organizations (NGOs), private companies, and governments (in countries where it operated) whilst The Max Foundation provided psychosocial support and education.

In 2017, it was reported that since the inception of GIPAP, the program had served the CML treatment needs of approximately 75,000 patients [8]. Over time, Novartis and The Max Foundation recognized a more flexible approach to treatment access was needed, which led to a new collaboration in 2017 called the CMLPath to Care ${ }^{\text {TM }}$ that replaced GIPAP. Under the new collaboration, The Max Foundation was responsible for supply chain management and treatment delivery to patients, whilst Novartis provides funding and medicine donation support. CMLPath to Care ${ }^{\text {TM }}$ aims to support continued access to treatment at no cost for the nearly 34000 previously registered patients in GIPAP with CML, GIST, and other rare cancers that responded to Imatinib. The program has been reported to run in 68 countries in the following regions: East Asia, Pacific, Europe, Central Asia, Latin America, Caribbean, Middle East, North Africa, South Asia, and SubSaharan Africa [9].

Due to TKIs use and the subsequent improved global CML survival rates, there has been an increase in the prevalence of CML [2]. The 2040 prevalence of CML has been estimated to be 250000 patients in the United States of America (USA) due to the success of Imatinib increasing survival [10]. As TKI treatment attracts a high cost and against a backdrop of recommended lifelong therapy [4], this can translate to a significant burden on healthcare systems. A systematic review that focused on the economic burden associated with CML treatment in the United States noted that CML poses a significant economic burden influenced by prescriptions, inpatient and outpatient costs, adherence and costs related to adverse events, switching between medications, and treatment failure [11]. As per the European LeukemiaNet (ELN), the ultimate goal of CML treatment is normal survival and good quality of life without lifelong treatment. However, in resourcepoor countries, which are affected by the unavailability of effective drugs and limited essential monitoring, the goal of treatment remains as survival [12].

\section{Aim and objectives}

The aim was to compare the cost profiles of TKIs registered in SA for the treatment of CML.

To achieve this, the following specific objectives were outlined:

- To track the regulatory approvals of TKIs in SA (up to 2019).

- To compare the 2019 cost profiles of TKIs available in the private and public sectors of SA.

\section{Research Methodology}




\section{Study design}

The study was descriptive, quantitative, and retrospective in nature. The study employed a secondary research design in that existing data available from public domain documents were collected, analysed, and interpreted.

\section{Data source}

\section{Public domain website}

The South African Health Products Regulatory Authority (SAHPRA) website was searched on 20 August 2019 to track the regulatory approval of TKIs used in $\mathrm{CML}(\mathrm{CP})$ treatment in SA, by searching the active pharmaceutical ingredient terms "Imatinib", "Nilotinib" and "Dasatinib" under the registered health products portal.

\section{Public domain documents}

The 2019 Medicines Price Registry [13] and Department of Health (DOH) awarded tenders for oncology medication for the 2019 period [6] were reviewed to extract pricing data of TKIs in the private and public sectors respectively.

\section{Data Analysis}

Medicines' registration and pricing data of TKIs available in the South African private and public health care sectors were collected and entered into Microsoft Excel $\rightarrow$ (version 2016), periodically sorted and analysed after complete entry.

\section{Ethical Considerations}

Ethical approval for the study was obtained from the University of KwaZulu-Natal's Biomedical Research Ethics Committee (BREC/00000486/2019) under the expedited approval process as the nature of the study involved data available in the public domain.

\section{Results}

\section{Registered TKIs in South Africa}

There were three (3) TKI active pharmaceutical ingredients (APIs) registered in South Africa: Imatinib, Nilotinib, and Dasatinib. These APIs are formulated in different strengths and dosage forms, and the South African market had 21 duly registered TKI formulations (Table 1). Imatinib had been presented in 50 mg, 100 mg, and 400 mg; Nilotinib in 150 mg and $200 \mathrm{mg}$; and Dasatinib in 20 mg, 50 mg, 70 mg, and 100 mg strengths of capsules and tablets. 
Table 1

TKIs registered by SAHPRA for CML(CP) (2019)

\begin{tabular}{|c|c|c|c|c|c|}
\hline SN & $\begin{array}{l}\text { Registered } \\
\text { Number }\end{array}$ & $\begin{array}{l}\text { SAHPRA } \\
\text { Registered date }\end{array}$ & Proprietary name & $\begin{array}{l}\text { Dosage } \\
\text { form }\end{array}$ & Active Ingredient/s and strength \\
\hline 1 & $36 / 34 / 0138$ & $5 / 20 / 2002$ & GLEEVEC 50 & Capsule & Imatinib 50,0 mg \\
\hline 2 & $36 / 34 / 0139$ & $5 / 20 / 2002$ & GLEEVEC 100 & Capsule & Imatinib 100,0 mg \\
\hline 3 & $38 / 34 / 0143$ & $11 / 25 / 2005$ & GLEEVEC & Tablet & $\begin{array}{l}\text { Imatinib mesilate equivalent to } \\
\text { Imatinib 100,0 mg }\end{array}$ \\
\hline 4 & $38 / 34 / 0144$ & $11 / 25 / 2005$ & GLEEVEC 400 & Tablet & $\begin{array}{l}\text { Imatinib mesilate equivalent to } \\
\text { Imatinib } 400,0 \mathrm{mg}\end{array}$ \\
\hline 5 & $41 / 26 / 1039$ & $12 / 9 / 2008$ & $\begin{array}{l}\text { SPRYCEL } 20 \mathrm{mg} \\
\text { TABLETS }\end{array}$ & Tablet & Dasatinib 20,0 mg \\
\hline 6 & $41 / 26 / 1040$ & $12 / 9 / 2008$ & $\begin{array}{l}\text { SPRYCEL } 50 \mathrm{mg} \\
\text { TABLETS }\end{array}$ & Tablet & Dasatinib 50,0 mg \\
\hline 7 & $41 / 26 / 1041$ & $12 / 9 / 2008$ & $\begin{array}{l}\text { SPRYCEL } 70 \mathrm{mg} \\
\text { TABLETS }\end{array}$ & Tablet & Dasatinib 70,0 mg \\
\hline 8 & $41 / 26 / 0973$ & $12 / 4 / 2009$ & TASIGNA 200 mg & Capsule & Nilotinib 200,0 mg \\
\hline 9 & $42 / 34 / 0496$ & $3 / 2 / 2012$ & IMAVEC & Capsule & $\begin{array}{l}\text { Imatinib mesilate equivalent to } \\
\text { Imatinib } 100,0 \mathrm{mg}\end{array}$ \\
\hline 10 & $44 / 26 / 0205$ & $12 / 7 / 2012$ & $\begin{array}{l}\text { SPRYCEL } 100 \mathrm{mg} \\
\text { TABLETS }\end{array}$ & Tablet & Dasatinib $100,0 \mathrm{mg}$ \\
\hline 11 & $45 / 26 / 0410$ & $3 / 1 / 2013$ & TASIGNA $150 \mathrm{mg}$ & Capsule & Nilotinib 150,0 mg \\
\hline 12 & $44 / 26 / 0886$ & $12 / 5 / 2013$ & SUNMATIN 400 & Tablet & $\begin{array}{l}\text { Imatinib mesilate equivalent to } \\
\text { Imatinib } 400,0 \mathrm{mg}\end{array}$ \\
\hline 13 & $44 / 26 / 0887$ & $12 / 5 / 2013$ & SUNMATIN 100 & Tablet & $\begin{array}{l}\text { Imatinib mesilate equivalent to } \\
\text { Imatinib } 100,0 \mathrm{mg}\end{array}$ \\
\hline 14 & $49 / 26 / 0740$ & $9 / 30 / 2016$ & $\begin{array}{l}\text { IMATINIB ACCORD } \\
100\end{array}$ & Tablet & $\begin{array}{l}\text { Imatinib mesilate equivalent to } \\
\text { Imatinib } 100,0 \mathrm{mg}\end{array}$ \\
\hline 15 & $49 / 26 / 0741$ & $9 / 30 / 2016$ & $\begin{array}{l}\text { IMATINIB ACCORD } \\
400\end{array}$ & Tablet & $\begin{array}{l}\text { Imatinib mesilate equivalent to } \\
\text { Imatinib } 400,0 \mathrm{mg}\end{array}$ \\
\hline 16 & $49 / 26 / 0742$ & $9 / 30 / 2016$ & MIVESTA 100 & Tablet & $\begin{array}{l}\text { Imatinib mesilate equivalent to } \\
\text { Imatinib } 100,0 \mathrm{mg}\end{array}$ \\
\hline 17 & $49 / 26 / 0743$ & $9 / 30 / 2016$ & MIVESTA 400 & Tablet & $\begin{array}{l}\text { Imatinib mesilate equivalent to } \\
\text { Imatinib } 400,0 \mathrm{mg}\end{array}$ \\
\hline 18 & $46 / 26 / 0367$ & $9 / 30 / 2016$ & VATIVIO FC & Tablet & $\begin{array}{l}\text { Imatinib mesilate equivalent to } \\
\text { Imatinib } 100,0 \mathrm{mg}\end{array}$ \\
\hline 19 & $46 / 26 / 0368$ & $9 / 30 / 2016$ & NAZZEC 400 & Tablet & $\begin{array}{l}\text { Imatinib mesilate equivalent to } \\
\text { Imatinib } 400,0 \mathrm{mg}\end{array}$ \\
\hline 20 & $46 / 26 / 0369$ & $9 / 30 / 2016$ & VATIVIO 100 & Tablet & $\begin{array}{l}\text { Imatinib mesilate equivalent to } \\
\text { Imatinib } 100,0 \mathrm{mg}\end{array}$ \\
\hline 21 & $46 / 26 / 0370$ & $9 / 30 / 2016$ & NAZZEC 400 & Tablet & $\begin{array}{l}\text { Imatinib mesilate equivalent to } \\
\text { Imatinib } 400,0 \mathrm{mg}\end{array}$ \\
\hline \multicolumn{6}{|c|}{$\begin{array}{l}\text { [Table } 1 \text { contains the tyrosine kinase inhibitors that were registered in South Africa as of } 2019 \text {, for the treatment of } \\
\text { CML(CP). Abbreviations: SAHPRA - South African Health Products Regulatory Authority, TKI- Tyrosine kinase inhibito } \\
\text { CML(CP) - Chronic myeloid leukemia chronic phase] }\end{array}$} \\
\hline
\end{tabular}




\section{Cost comparison}

All three TKI APIs were available in the private health sector, however, only Imatinib and Nilotinib were available in the public sector. In SA, generics were only available for Imatinib. Cost comparisons were only possible for Imatinib $100 \mathrm{mg}$, Imatinib $400 \mathrm{mg}$, and Nilotinib $200 \mathrm{mg}$, as these TKIs were the only TKls available in both the private and public sectors. The cost profiles of the available TKIs in the South African private and public health care sectors have been presented (Table 2). 
Table 2

Cost profiles of TKls available in the South African private and public health care sectors (2019).

\begin{tabular}{|c|c|c|c|c|c|c|c|c|c|}
\hline \multirow{2}{*}{$\begin{array}{l}\text { Medicine } \\
\text { Proprietary } \\
\text { Name }\end{array}$} & \multirow{2}{*}{$\begin{array}{l}\text { Active } \\
\text { Ingredients }\end{array}$} & \multirow[t]{2}{*}{ Strength } & \multirow{2}{*}{$\begin{array}{l}\text { Dosage } \\
\text { Form }\end{array}$} & \multirow{2}{*}{$\begin{array}{l}\text { Pack } \\
\text { Size }\end{array}$} & \multirow{2}{*}{$\begin{array}{l}\text { Originator } \\
\text { or } \\
\text { Generic }\end{array}$} & \multicolumn{2}{|c|}{ Private Sector } & \multicolumn{2}{|c|}{ Public Sector } \\
\hline & & & & & & $\begin{array}{l}\text { Single } \\
\text { Exit } \\
\text { Price } \\
\text { (ZAR) }\end{array}$ & $\begin{array}{l}\text { Unit } \\
\text { Price } \\
\text { (ZAR) }\end{array}$ & $\begin{array}{l}\text { Tender } \\
\text { Contract } \\
\text { Price } \\
\text { (ZAR) }\end{array}$ & $\begin{array}{l}\text { Unit } \\
\text { Price } \\
\text { (ZAR) }\end{array}$ \\
\hline $\begin{array}{l}\text { Gleevec } \\
100 \mathrm{mg}\end{array}$ & Imatinib & $100 \mathrm{mg}$ & $\mathrm{TAB}$ & 60 & Originator & $\begin{array}{l}22 \\
281.56\end{array}$ & 371.36 & N/A & $\mathrm{N} / \mathrm{A}$ \\
\hline $\begin{array}{l}\text { Imatinib } \\
\text { accord } \\
100 \mathrm{mg}\end{array}$ & Imatinib & 100 mg & $\mathrm{TAB}$ & 60 & Generic & 6578.00 & 109.63 & 224.25 & 3.74 \\
\hline $\begin{array}{l}\text { Mivesta } \\
100 \text { mg }\end{array}$ & Imatinib & 100 mg & FCT & 60 & Generic & 6548.16 & 109.14 & N/A & $\mathrm{N} / \mathrm{A}$ \\
\hline $\begin{array}{l}\text { Imavec } \\
100 \mathrm{mg}\end{array}$ & $\begin{array}{l}\text { Imatinib } \\
\text { Mesylate }\end{array}$ & $100 \mathrm{mg}$ & CAP & 60 & Generic & 7174.43 & 119.57 & $\mathrm{~N} / \mathrm{A}$ & N/A \\
\hline $\begin{array}{l}\text { Vativio } \\
100 \mathrm{mg}\end{array}$ & Imatinib & $100 \mathrm{mg}$ & CAP & 120 & Generic & $\begin{array}{l}14 \\
299.46\end{array}$ & 119.16 & $\mathrm{~N} / \mathrm{A}$ & $\mathrm{N} / \mathrm{A}$ \\
\hline $\begin{array}{l}\text { Sunmatin } \\
100 \mathrm{mg}\end{array}$ & $\begin{array}{l}\text { Imatinib } \\
\text { Mesylate }\end{array}$ & $100 \mathrm{mg}$ & FCT & 60 & Generic & 6800.34 & 113.34 & N/A & N/A \\
\hline $\begin{array}{l}\text { Gleevec } \\
400 \mathrm{mg}\end{array}$ & Imatinib & 400 mg & $\mathrm{TAB}$ & 30 & Originator & $\begin{array}{l}44 \\
563.16\end{array}$ & 1485.44 & N/A & N/A \\
\hline $\begin{array}{l}\text { Imavec } \\
400 \mathrm{mg}\end{array}$ & $\begin{array}{l}\text { Imatinib } \\
\text { Mesylate }\end{array}$ & $400 \mathrm{mg}$ & CAP & 30 & Originator & $\begin{array}{l}13 \\
091.92\end{array}$ & 436.40 & N/A & N/A \\
\hline $\begin{array}{l}\text { Imatinib } \\
\text { accord } \\
400 \mathrm{mg}\end{array}$ & Imatinib & 400 mg & FCT & 30 & Generic & $\begin{array}{l}12 \\
648.85\end{array}$ & 421.63 & 454.25 & 15.14 \\
\hline $\begin{array}{l}\text { Imavec } \\
400 \mathrm{mg}\end{array}$ & Imatinib & 400 mg & FCT & 30 & Generic & $\begin{array}{l}12 \\
593.64\end{array}$ & 419.79 & N/A & $\mathrm{N} / \mathrm{A}$ \\
\hline $\begin{array}{l}\text { Vativio } \\
400 \text { mg }\end{array}$ & Imatinib & 400 mg & $\mathrm{TAB}$ & 30 & Generic & $\begin{array}{l}13 \\
000.00\end{array}$ & 433.33 & N/A & N/A \\
\hline $\begin{array}{l}\text { Sunmatin } \\
100 \mathrm{mg}\end{array}$ & $\begin{array}{l}\text { Imatinib } \\
\text { mesilate }\end{array}$ & $400 \mathrm{mg}$ & FCT & 30 & Generic & $\begin{array}{l}13 \\
091.92\end{array}$ & 436.40 & N/A & N/A \\
\hline $\begin{array}{l}\text { Tasigna } \\
200 \mathrm{mg}\end{array}$ & $\begin{array}{l}\text { Nilotinib } \\
\text { Hydrochloride } \\
\text { Monohydrate }\end{array}$ & 200 mg & CAP & 112 & Originator & $\begin{array}{l}28 \\
823.04\end{array}$ & 257.35 & 2176.28 & 19.43 \\
\hline $\begin{array}{l}\text { Tasigna } \\
150 \text { mg }\end{array}$ & Nilotinib & 150 mg & CAP & 112 & Originator & $\begin{array}{l}21 \\
617.29\end{array}$ & 193.01 & N/A & N/A \\
\hline $\begin{array}{l}\text { Sprycel } 20 \\
\text { mg tablets }\end{array}$ & Dasatinib & $20 \mathrm{mg}$ & $\mathrm{TAB}$ & 60 & Originator & 8758.94 & 145.98 & $\begin{array}{l}\text { Re- } \\
\text { tender: } \\
\text { No } \\
\text { Quote }\end{array}$ & $\begin{array}{l}\text { Re- } \\
\text { tender: } \\
\text { No } \\
\text { Quote }\end{array}$ \\
\hline
\end{tabular}

[Table 2 contains TKI prices for each originator and branded TKI medicine available in South Africa in 2019. South African currency is quoted in ZAR, Public sector tender contract prices are inclusive of $15 \%$ Value Added Tax, Private sector prices are based on Single Exit Price (SEP) $=$ ex- manufacturers price + logistic fee + VAT. Average cost/unit of Imatinib $100 \mathrm{mg}$ generic = ZAR 114.17. Average cost/unit of Imatinib $400 \mathrm{mg}$ generic = ZAR 427.79. Abbreviations: CAP - Capsule, FCT - Film coated tablet, TAB - Tablet, TKI - Tyrosine kinase inhibitor] 


\begin{tabular}{|c|c|c|c|c|c|c|c|c|c|}
\hline \multirow{2}{*}{$\begin{array}{l}\text { Medicine } \\
\text { Proprietary } \\
\text { Name }\end{array}$} & \multirow{2}{*}{$\begin{array}{l}\text { Active } \\
\text { Ingredients }\end{array}$} & \multirow[t]{2}{*}{ Strength } & \multirow{2}{*}{$\begin{array}{l}\text { Dosage } \\
\text { Form }\end{array}$} & \multirow{2}{*}{$\begin{array}{l}\text { Pack } \\
\text { Size }\end{array}$} & \multirow{2}{*}{$\begin{array}{l}\text { Originator } \\
\text { or } \\
\text { Generic }\end{array}$} & \multicolumn{2}{|c|}{ Private Sector } & \multicolumn{2}{|c|}{ Public Sector } \\
\hline & & & & & & $\begin{array}{l}\text { Single } \\
\text { Exit } \\
\text { Price } \\
\text { (ZAR) }\end{array}$ & $\begin{array}{l}\text { Unit } \\
\text { Price } \\
\text { (ZAR) }\end{array}$ & $\begin{array}{l}\text { Tender } \\
\text { Contract } \\
\text { Price } \\
\text { (ZAR) }\end{array}$ & $\begin{array}{l}\text { Unit } \\
\text { Price } \\
\text { (ZAR) }\end{array}$ \\
\hline $\begin{array}{l}\text { Sprycel } 50 \\
\text { mg tablets }\end{array}$ & Dasatinib & $50 \mathrm{mg}$ & TAB & 60 & Originator & $\begin{array}{l}21 \\
897.38\end{array}$ & 364.96 & $\begin{array}{l}\text { Re- } \\
\text { tender: } \\
\text { No } \\
\text { Quote }\end{array}$ & $\begin{array}{l}\text { Re- } \\
\text { tender: } \\
\text { No } \\
\text { Quote }\end{array}$ \\
\hline $\begin{array}{l}\text { Sprycel } 70 \\
\text { mg tablets }\end{array}$ & Dasatinib & $70 \mathrm{mg}$ & TAB & 60 & Originator & $\begin{array}{l}30 \\
607.26\end{array}$ & 510.12 & $\begin{array}{l}\text { Re- } \\
\text { tender: } \\
\text { No } \\
\text { Quote }\end{array}$ & $\begin{array}{l}\text { Re- } \\
\text { tender: } \\
\text { No } \\
\text { Quote }\end{array}$ \\
\hline $\begin{array}{l}\text { Sprycel } \\
100 \mathrm{mg} \\
\text { tablets }\end{array}$ & Dasatinib & $100 \mathrm{mg}$ & $\mathrm{TAB}$ & 30 & Originator & $\begin{array}{l}21 \\
897.37\end{array}$ & 729.91 & $\begin{array}{l}\text { Re- } \\
\text { tender: } \\
\text { No } \\
\text { Quote }\end{array}$ & $\begin{array}{l}\text { Re- } \\
\text { tender: } \\
\text { No } \\
\text { Quote }\end{array}$ \\
\hline \multicolumn{10}{|c|}{$\begin{array}{l}\text { [Table } 2 \text { contains TKI prices for each originator and branded TKI medicine available in South Africa in 2019. South } \\
\text { African currency is quoted in ZAR, Public sector tender contract prices are inclusive of } 15 \% \text { Value Added Tax, Private } \\
\text { sector prices are based on Single Exit Price }(\text { SEP })=\text { ex- manufacturers price + logistic fee + VAT. Average cost/unit of } \\
\text { Imatinib } 100 \mathrm{mg} \text { generic = ZAR } 114.17 \text {. Average cost/unit of Imatinib } 400 \mathrm{mg} \text { generic = ZAR } 427.79 \text {. Abbreviations: } \\
\text { CAP - Capsule, FCT - Film coated tablet, TAB - Tablet, TKI - Tyrosine kinase inhibitor] }\end{array}$} \\
\hline
\end{tabular}

\section{Imatinib $100 \mathrm{mg}$}

Treatment costs between ZAR 109.14 - ZAR 371.36/per unit in the private sector compared to ZAR 3.74/unit in the public sector. In the private sector, the average generic cost was ZAR 114.17/unit compared to the originator at ZAR 371.36/unit.

\section{Imatinib $400 \mathrm{mg}$}

Monthly treatment costs between ZAR 12593.64 - ZAR 44563.16 in the private sector which is much higher compared to ZAR 454.25 per month in the public sector.

\section{Nilotinib $200 \mathrm{mg}$}

Only the originator was available in both health sectors, but prices varied, i.e., ZAR 257.35/unit in the private sector compared to ZAR 19.43 /unit in the public sector.

\section{Discussion}

It is well known that the health care framework in South Africa is divided into the private and public sectors, each with varying medicine funding sources and pricing systems [14]. The most prominent observation from the study was that all private sector Single Exit Prices (SEP) were consistently higher than public sector tender contract prices.

The recommended first-line treatment for CML-CP is Imatinib 400 mg/daily, which costs between ZAR 12593.64 - ZAR 44 563.16 per month in the private sector, compared to ZAR 454.25 per month in the public sector. The private health care sector is funded largely by private medical insurance and out-of-pocket funding. The private sector does not utilize a tendering system and therefore usually does not realize the benefit of lower procurement costs as seen in the public sector [15]. Louw et al. (2011) noted a concerning trend where patients in the private sector were refused TKI therapy due to cost implications. Unfortunately, this resulted in poor patient outcomes because these patients did not qualify for the patient 
assistance programs provided in the public sector [2]. It is therefore important that stakeholders engage in valuable discussions to address and lower these cost and access inequalities.

Imatinib-resistant or intolerant patients are generally treated with $400 \mathrm{mg}$ of nilotinib twice daily. In 2019 nilotinib $200 \mathrm{mg}$ was only available as the originator product in SA, costing ZAR 257.35/unit (or ZAR 28 823.04/month) for private-sector patients, whereas the same medicine translated to a $92.4 \%$ decrease in price at ZAR 19.43/unit (or ZAR 2176.28/month) for public sector patients. The public sector is funded by the South African government and utilizes a pharmaceutical tendering system where medicines are purchased in bulk and at fixed prices over specific periods of the contract. This in turn provides the public sector with the advantage of pricing competition and achieving economies of scale for a larger number of patients [15]. Unfortunately for private-sector patients, access to treatment will still be hindered by affordability and generic availability. It is noted that four nilotinib patents were granted in South Africa between 2004 and 2009 and if unchallenged this could prevent the use of generic nilotinib products in South Africa until 2029 [16], further hindering treatment accessibility.

The study demonstrated the advantage of generic medicine introduction in lowering medicine prices in the private sector; five generics were available for Imatinib $100 \mathrm{mg}$. Imatinib $100 \mathrm{mg}$ originator drug costs ZAR 371.36/unit (or ZAR 22 281.56/60 units) compared to the average price for an Imatinib $100 \mathrm{mg}$ generic at ZAR 114.17/unit (or ZAR 6850.13/60 units) available in the private sector. However, these generic prices still do not compare to Imatinib available in the public sector at ZAR 3.74/unit (or ZAR 224.25/ 60 units).

Dasatinib is recommended as a second-line treatment of CML-CP in patients that are resistant or intolerant of Imatinib. Dasatinib is only available in the SA private sector, with cost implications of ZAR 21897.37 for a one-month course of treatment (100 mg daily dose) and currently, there are no generics for Dasatinib approved by SAPHRA. Health economists estimate in the absence of patent monopolies, Dasatinib could be manufactured profitably for $£ 9$ (ZAR 150.00) per month [16]. The study findings also noted that no quotes were received for all strengths of Dasatinib in the public sector, and a retender was applicable. It is therefore important that stakeholders (pharmaceutical companies, patient advocating organizations, the National Department of Health, clinical treaters, policymakers, and public and private health care sectors) engage in conversations on how to achieve equitable treatment accessibility.

Access to TKIs has had a significant impact on the management of CML in SA [7]. In SA, additional avenues to improve access to TKIs include access through clinical trials and patient assistance programs. A successful patient assistance program called Glivec International Patient Assistance Program (GIPAP) was set up as a partnership between Novartis and The Max Foundation in 2002, which supplied imatinib at no cost to poorer patients [7, 8]. Smaller patient assistance programs were also established in South Africa to facilitate access to Nilotinib and Dasatinib for patients intolerant or resistant to Imatinib. However, challenges remain and include patient illiteracy, language barriers, co-infection with HIV, and far travel distances from treatment centres [7].

Although TKI prices appear more favourable to the public health sector, overall TKIs remain unaffordable in the SA public healthcare setting as it is accessed by approximately $80 \%$ of the population. Additionally, the public sector is burdened by a high prevalence of communicable, non-communicable diseases and HIV, which inherently limits resources available to procure and access expensive oncology medicines [7]. As with the advancement of medicine, the aim of developing TKIs was to alleviate pain and suffering by slowing disease progression, further the introduction of TKI generics should provide affordable treatment options. However high TKI costs in the 21 st century still result in a significant economic burden influenced by prescription, inpatient and outpatient costs, adherence and costs related to adverse events, switching, poor compliance, treatment failure, which has been noted in both developing and developed countries [11].

\section{Limitations}


CML and TKI usage data in SA is scant and therefore the direct economic burden on the private versus public health care system could not be established. The study focused on TKIs used for CML treatment in the CP and not the AP and BP stages. Data regarding the available TKIs through a donation program was not detailed in the results. Basic cost comparisons were done between TKIs; however, the cost of monitoring and patient management has not been established in the study and requires further investigation for a full economic evaluation.

\section{Conclusion}

In general, and across all TKIs available in SA, treatment for CML-CP patients in the private sector is largely more expensive than treatment in the public sector. Imatinib generics are available, which results in more competitive pricing and affordable treatment options for patients. However, there were no generics available for Nilotinib and Dasatinib in SA at the time of the study. It is well known that patent monopolies create barriers to generic entry globally; however in the context of targeted oncology therapy, the high cost of oncology treatment including monitoring, and management, further strains the health care systems. Previously CML experts expressed that high CML treatment costs are unsustainable, may compromise treatment access to highly effective therapy, and is harmful to the sustainability of national health care systems [17]. This study highlights that urgent discussions between stakeholders on improving approval regulation, pricing regulation, use of risk-sharing health care models, and policy changes are required between stakeholders in both the private and public health care sectors so that patients can access the highly effective TKI therapy that is currently available.

\section{Abbreviations}

AP

Accelerated Phase; APIs:Active Pharmaceutical Ingredients; BP:Blast Phase; CAP:Capsule; CML:Chronic Myeloid Leukemia; CML-CP:Chronic Myeloid Leukemia Chronic Phase; CP:Chronic Phase; DOH:Department of Health; ELN:European LeukemiaNet; FCT:Film-coated tablet; GIPAP:Glivec International Patient Assistance Program; GIST:Gastrointestinal Stromal Tumor; HIV:Human Immunodeficiency Virus; NGOs:non-governmental organizations; SA:South Africa; SAHPRA:South African Health Products Regulatory Authority; SEP:Single Exit Price; TAB:Tablet; TKIs:Tyrosine Kinase Inhibitors; USA:United States of America; VAT:Value Added Tax; ZAR:South African Rand.

\section{Declarations}

\section{Acknowledgment}

The authors acknowledge the management of the University of KwaZulu-Natal.

\section{Authors' contributions}

R.S. designed the study, collected data, analysed the results and drafted the manuscript.

E.W. checked the data for completeness, prepared the table of results and reviewed the manuscript.

F.O., K.B.M. and V.B. designed the study, reviewed the manuscript and supervised the study.

All the authors read and approved the manuscript for publication.

\section{Funding}

None. 
Availability of data and materials

None.

\section{Ethics approval and consent to participate}

Ethical approval was granted by the University of KwaZulu-Natal (BREC/00000486/2019). There was no consent to participate because the study did not collect data from study subjects.

\section{Consent for publication}

None.

\section{Conflicts of interest}

The authors declare they have no conflicts of interest.

\section{ORCID identifiers}

Reeya Singh: https://orcid.org/0000-0002-7349-5548

Frasia Oosthuizen: https://orcid.org/0000-0003-3691-7446

Ebenezer Wiafe: https://orcid.org/0000-0002-0496-5737

Kofi Boamah Mensah: https://orcid.org/0000-0002-7971-4270

Varsha Bangalee: https://orcid.org/0000-0002-9613-1501

\section{References}

1. Tabarestani, S. and A. Movafagh, New developments in chronic myeloid leukemia: implications for therapy. Iranian journal of cancer prevention, 2016. 9(1).

2. Louw, V., et al., Recommendations for the management of adult chronic myeloid leukaemia in South Africa: guideline. South African Medical Journal, 2011. 101(11): p. 840-846.

3. Landgren, C.O., et al., Daratumumab monotherapy for patients with intermediate-risk or high-risk smoldering multiple myeloma: a randomized, open-label, multicenter, phase 2 study (CENTAURUS). Leukemia, 2020. 34(7): p. 1840-1852.

4. Baccarani, M., et al., European LeukemiaNet recommendations for the management of chronic myeloid leukemia: 2013. Blood, The Journal of the American Society of Hematology, 2013. 122(6): p. 872-884.

5. SAHPRA: South African Health Products Registration. Registered Health Products. 2019; Available from: https://www.sahpra.org.za/.

6. Department of Health. Expired Pharmaceutical Contracts: Supply and delivery of Oncology and immunological agents to the state (June 2018-December 2020). 2018; Available from: http://www.health.gov.za/tenders/.

7. Louw, V., Chronic myeloid leukaemia in South Africa. Hematology, 2012. 17(sup1): p. s75-s78.

8. Novartis International AG. Novartis and The Max Foundation transform pioneering cancer access program for people in lower-income countries. 2017; Available from: https://www.novartis.com/news/media-releases/novartis-and-maxfoundation-transform-pioneering-cancer-access-program-people-lower-income-countries.

9. Global Health Progress. CMLPath to Care. 2017; Available from: https://globalhealthprogress.org/collaboration/cmlpath-to-care/. 
10. O'Hare, T. and M.W. Deininger, Toward a cure for chronic myeloid leukemia. Clinical Cancer Research, 2008. 14(24): p. 7971-7974.

11. Gala, S., A. Shah, and M. Mwamburi, Economic burden associated with chronic myeloid leukemia (CML) treatments in the United States: a systematic literature review. Value in Health, 2016. 19(7): p. A727.

12. Hochhaus, A., et al., European LeukemiaNet 2020 recommendations for treating chronic myeloid leukemia. Leukemia, 2020. 34(4): p. 966-984.

13. Health-e. Medicine Price Registry. 2019; Available from: https://health-e.org.za/medicine-price-registry/.

14. Burger, R. and C. Christian, Access to health care in post-apartheid South Africa: availability, affordability, acceptability. Health Economics, Policy and Law, 2020. 15(1): p. 43-55.

15. Wouters, O.J., et al., The impact of pharmaceutical tendering on prices and market concentration in South Africa over a 14-year period. Social Science \& Medicine, 2019. 220: p. 362-370.

16. Tomlinson, C., et al. Exploring patent barriers to cancer treatment access in South Africa. 2017; Available from: https://infojustice.org/archives/38950.

17. Experts in Chronic Myeloid Leukemia, The price of drugs for chronic myeloid leukemia $(C M L)$ is a reflection of the unsustainable prices of cancer drugs: from the perspective of a large group of CML experts. Blood, The Journal of the American Society of Hematology, 2013. 121(22): p. 4439-4442. 